\title{
The sea-blue histiocyte syndrome with hepatic porphyria and infectious mononucleosis
}

\author{
M. L. GHOSH \\ From the District General Hospital, Barnsley, Yorkshire
}

SYNOPSIS The syndrome of sea-blue histiocyte, hepatic porphyria, and infectious mononucleosis occurring simultaneously in a young girl is described. The cytochemical staining character of the bone marrow histiocytes strongly suggested that the storage material was glycolipid. The possible relationship between the multiple disorders in the same patient is discussed.

Sawitsky, Hyman, and Hyman (1954) initially described two patients with splenomegaly and large number of peculiar histiocytes in the bone marrow and spleen containing cytoplasmic storage granules staining blue with Romanowsky's stain. Since then more than a dozen cases, including siblings (Jones, Gilbert, Zugibe, and Thompson, 1970; Lake, Stephens, and Neville, 1970) have been reported. Silverstein, Ellefson, and Ahern (1970) used the term 'sea-blue histiocyte syndrome' for this condition. Furthermore, the coexistence of sea-blue histiocytes and some haematological disorders such as myelofibrosis (Marshall and Adams, 1958) and sickle-cell disease (Kattlove, Gaynor, Spivack, and Gottfried, 1970) have also been reported.

The present patient is the first reported case of sea-blue histiocyte syndrome associated with acute intermittent hepatic porphyria and infectious mononucleosis.

\section{Case Report}

A 17-year-old girl presented with a two-month history of acute intermittent colicky abdominal pain, nausea, occasional vomiting, and tiredness. She gave a vague history of sore throat. During the course of her illness she noticed that her urine became dark red. Her past history was non-contributory. There was no history suggestive of porphyria in other members of the family. Physical examination revealed no lymphadenopathy, no jaundice, and no abnormality of the skin. The tonsils and throat were slightly congested; the liver and spleen were just palpable. The rest of the physical examination did not show any abnormality.

Received for publication 17 August 1972.

$2^{*}$
IN VESTIGATIONS

Haemoglobin was $14 \cdot 2 \mathrm{~g} / 100 \mathrm{ml}$, WBC $11200 / \mathrm{mm}^{3}$ (neutrophils $23 \%$, lymphocytes $75 \%$, and monocytes $2 \%$ ). A blood film showed that almost all the lymphocytes were abnormal in morphology and typical of infectious mononucleosis. Platelets were $125000 / \mathrm{mm}^{3}$. The ESR was $45 \mathrm{~mm} /$ one hour. The bleeding time, clotting time, and prothrombin time were all normal. A Paul-Bunnell test gave positive result with a 1 in 112 dilution after absorption with guinea-pig kidney antigen. Bone marrow aspiration stained with Giemsa's stain showed normal cellular components with many large histiocytes containing blue granules in the cytoplasm (see Fig.). A cytochemical stain was strongly PAS positive and Sudan Black was moderately positive suggesting that the storage material in the cytoplasm was glycolipid.

Liver function tests showed bilirubin $0.8 \mathrm{mg} / 100$

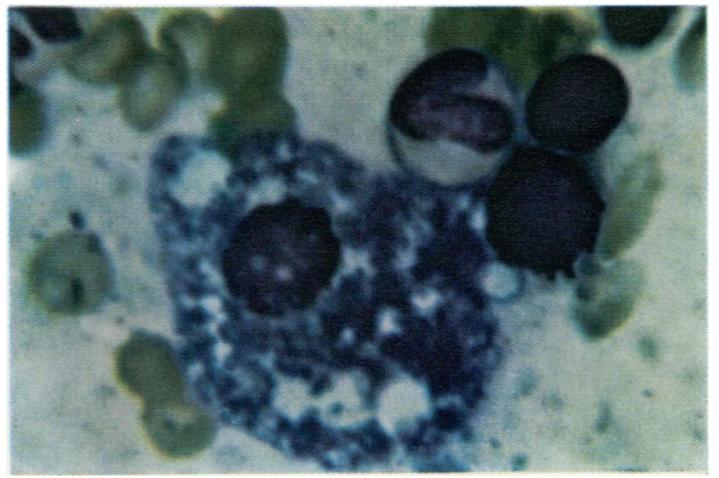

Fig. Bone marrow aspiration stained with Giemsa's stain showing typical sea-blue histiocyte $\times 600$. 
$\mathrm{ml}$, SGOT $54 \mathrm{mIU} / \mathrm{ml}$, SGPT $62 \mathrm{mIU} / \mathrm{ml}$, ICDH $16 \mathrm{mIU} / \mathrm{ml}$. Alkaline phosphatase was $9 \mathrm{KA}$ units; serum cholesterol $170 \mathrm{mg} / 100 \mathrm{ml}$, blood urea $38 \mathrm{mg} \%$, serum albumin $5.3 \mathrm{~g} / 100 \mathrm{ml}$. Serum immunoglobulin estimation showed IgG 2000 $\mathrm{mg} / 100 \mathrm{ml}$, IgA $175 \mathrm{mg} / 100 \mathrm{ml}$, IgM $236 \mathrm{mg} / 100 \mathrm{ml}$. Antinuclear factor not detected.

Urine showed an increase in bilirubin and urobilinogen and porphyrins but no mucopolysaccharide was detected. The full porphyrin analysis results (see Table) confirmed the diagnosis of acute intermittent hepatic porphyria.

\begin{tabular}{lll}
\hline Porphyrin Analysis Results & Normal Values \\
\hline $\begin{array}{l}\text { Erythrocyte } \\
\text { coproporphyrin }\end{array}$ & $0.61 \mu \mathrm{g} / 100 \mathrm{ml}$ & $<4.2 \mu \mathrm{g} / 100 \mathrm{ml}$ cells \\
$\begin{array}{l}\text { Erythrocyte } \\
\text { protoporphyrin }\end{array}$ & $39.6 \mu \mathrm{g} / 100 \mathrm{ml}$ & $<35 \mu \mathrm{g} / 100 \mathrm{ml}$ cells \\
$\begin{array}{l}\text { Faecal } \\
\text { coproporphyrin }\end{array}$ & $15.6 \mu \mathrm{g} / \mathrm{g}$ dry wt & $<50 \mu \mathrm{g} / \mathrm{g} \mathrm{dry} \mathrm{wt}$ \\
$\begin{array}{l}\text { Faecal } \\
\text { protoporphyrin }\end{array}$ & $28.9 \mu \mathrm{g} / \mathrm{g}$ dry wt & $<113 \mu \mathrm{g} / \mathrm{g} \mathrm{dry} \mathrm{wt}$ \\
$\begin{array}{l}\text { Urinary } \\
\text { coproporphyrin }\end{array}$ & $573 \mu \mathrm{g} / 1$ & $<250 \mu \mathrm{g} / 1$ \\
$\begin{array}{l}\text { Urinary } \\
\text { uroporphyrin }\end{array}$ & $14272.9 \mu \mathrm{g} / 1$ & $<41 \mu \mathrm{g} / 1$ \\
$\begin{array}{l}\text { Urinary delta amino- } \\
\text { laevulinic acid }\end{array}$ & $77.6 \mathrm{mg} / 1$ & $<5.5 \mathrm{mg} / 1$ \\
$\begin{array}{l}\text { Urinary } \\
\text { porphobilinogen }\end{array}$ & $51 \mathrm{mg} / 1$ & $<3.5 \mathrm{mg} / 1$ \\
\hline
\end{tabular}

Table Porphyrin analysis in present case

\section{Discussion}

The essential features of this rare disorder are splenomegaly and the presence of large number of bright blue histiocytes in the bone marrow and spleen, although hepatomegaly and thrombocytopenia may be present. The cytochemical reaction on bone marrow smears in this patient and previous cases (Silverstein et al, 1970; Jones et al, 1970) suggested that the storage material in the cytoplasmic granules was glycolipid and/or phospholipid.

The aetiology of this lipid storage disease is unknown, but most of the reported cases were pre- $\square$ dominantly young females as is the subject of the present report. Some authors have suggested that it $\frac{}{.}$ is a hereditary disorder (Jones et al, 1970; Ardeman $\vec{\Rightarrow}$. and Lewis, 1972) but the disorder may be acquired $\stackrel{5}{+}$ and associated with other diseases (Marshall and Adams, 1958; Kattlove et al, 1970).

The present case is interesting in that the syndrome $\frac{\mathcal{N}}{\vec{D}}$

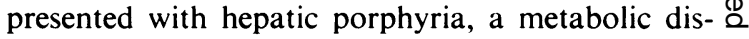
order of dominant inheritance, and infectious mono- ڤ nucleosis at the same time. The exact relationship $\overrightarrow{0}$ between the sea-blue histiocyte syndrome, porphyria, and infectious mononucleosis is not clear. It seems $\vec{\omega}$ that the sea-blue histiocyte syndrome and the por- 2 phyria are two hereditary metabolic disorders? present in this patient and the latter might have been precipitated by an attack of infectious mono- $\rightarrow$ nucleosis. On the other hand the sea-blue histiocyte $\vec{i}$ in the bone marrow may be an acquired abnormality $f$ coexisting with infectious mononucleosis similar to 0 other haematological disorders. Mild hepatosplenomegaly and thrombocytopenia may well be due to $z$ infectious mononucleosis. However, thrombocytopenia has been documented in this syndrome previously, as in this present case, but it should be followed up to ascertain this. Further biochemical and genetic studies are required to elucidate thg $\vec{\theta}$ pathogenesis of this entity.

References

Ardeman, S and Lewis, J. G (1972). Syndrome of the sea-blue histiocyte. Lancet, 1, 797.

Jones, B., Gilbert, E. F., Zugibe, F. T., and Thompson, H. (1970). Sea-blue histiocyte disease in siblings. Lancet, 2, 73-75.

Kattlove, H. E., Gaynor, E., Spivack, M., and Gottfried, E. L. (1970). Sea-blue indigestion. New Engl. J. Med., 282, 630-631.

Lake, B. D., Stephens, R., and Neville, B. G. R. (1970). Syndrome of the sea-blue histiocyte. Lancet, 2, 309.

Marshall, A. H. E., and Adams, C. W. M. (1958). An unusual form of lipidosis associated with thrombocytopenia and angiomata of the spleen. J. Path. Bact.. 76, 159-164.

Sawitsky, A., Hyman, G. A., and Hyman, J. B. (1954). An unidentified reticuloendothelial cell in bone marrow and spleen: Report of two cases with histochemical studies. Blood, 9, 977-985.

Silverstein, M. N., Ellefson, R. D., and Ahern, E. J. (1970). The syndrome of the sea-blue histiocyte. New Engl. J. Med., 282, $1-4$. 